\title{
Endothelial Cells Stimulated with Tumor Necrosis Factor- $\alpha$ Express Varying Amounts of Tissue Factor Resulting in Inhomogenous Fibrin Deposition in a Native Blood Flow System

\author{
Effects of Thrombin Inhibitors
}

Daniel Kirchhofer, Thomas B. Tschopp, Paul Hadváry, and Hans R. Baumgartner

Pharma Division, Preclinical Research, F. Hoffmann-La Roche Ltd., 4002 Basel, Switzerland

\begin{abstract}
TNF- $\alpha$ induces changes in endothelial cell functions, such as upregulation of tissue factor, resulting in endothelial procoagulant activity which may play a role in disseminated intravascular coagulation. The procoagulant activity of TNF- $\alpha$-stimulated endothelial cell monolayers was studied in a human ex vivo native (nonanticoagulated) blood flow system using the three thrombin inhibitors recombinant hirudin, Ro 46-6240, and heparin. Under venous blood flow conditions (shear rate 65 $s^{-1}$ ) recombinant hirudin, $R o$ 46-6240, and heparin inhibited fibrin deposition on the endothelial cells by $50 \%$ at concentrations of 14,28 , and $412 \mathrm{ng} / \mathrm{ml}$, respectively. The highest tested concentrations of the thrombin inhibitors reduced the postchamber fibrinopeptide A levels from $713 \pm 69$ to $<70 \mathrm{ng} / \mathrm{ml}$. Surprisingly, even at relatively high inhibitor concentrations, some local fibrin deposits were found on TNF- $\alpha$-stimulated cells, suggesting that some endothelial cells possess higher procoagulant activity than others. Therefore, the surface expression pattern of tissue factor, the primary initiator of coagulation in this system, was examined by immunogold-silver staining. The results showed that the tissue factor density on the cell surface varied strongly among TNF- $\alpha$-stimulated endothelial cells. Using TNF receptor-selective agonistic mutants of TNF$\alpha$, it was demonstrated further that the heterogenous surface expression of tissue factor was mediated entirely by the 55-kD TNF receptor and did not involve the $75-\mathrm{kD}$ TNF receptor. We conclude that in this system TNF- $\alpha$ induces heterogenous tissue factor expression which may lead to a high local thrombin concentration, such that even in the presence of thrombin inhibitors focal fibrin deposition occurs. (J. Clin. Invest. 1994. 93:2073-2083.) Key words: endothelium • tissue factor • tumor necrosis factor $\bullet$ flow $\bullet$ antithrombotics
\end{abstract}

\section{Introduction}

The development and cellular composition of a thrombus are governed by the local shear stress, which is low in veins and high in arteries. Shear stress differentially affects fibrin and platelet deposition on thrombogenic surfaces, such as suben-

Address correspondence to Daniel Kirchhofer, Ph.D., Pharma Division, Preclinical Research, F. Hoffman-La Roche Ltd., Grenzacherstrasse 124, CH-4002 Basel, Switzerland.

Received for publication 8 October 1993 and in revised form 25 January 1994.

J. Clin. Invest.

(C) The American Society for Clinical Investigation, Inc.

$0021-9738 / 94 / 05 / 2073 / 11 \quad \$ 2.00$

Volume 93, May 1994, 2073-2083 dothelium, collagen, or the extracellular matrix of cultured endothelial cells (1-8). Increasing shear stress reduces fibrin deposition, while platelet deposition and thrombus formation increase. Moreover, it was reported recently that shear stress directly affects the activity of coagulation enzymes, as demonstrated by the shear stress-dependent increase in Factor X activation by tissue factor/Factor VIIa in an open flow system (9-11). These studies emphasize the relevance of flow conditions in studying the processes leading to thrombosis and in examining new therapeutic approaches.

Shear stress also modulates the extrinsic activation of coagulation mediated by perturbed endothelial cells (12). Normally, endothelial cells maintain an anticoagulant surface by expressing heparin-like structures $(13,14)$, thrombomodulin $(15$, 16), and components of the fibrinolytic system (17) and by secreting prostacyclin (18). However, in vitro, cytokines such as TNF- $\alpha(19-21)$, IL-1 $(22,23)$, and endotoxin (24) are known to change endothelial cells from an antihemostatic to a procoagulant state by inducing the expression of tissue factor and by modulating other cellular functions (25). Endothelial tissue factor may play a role in disseminated intravascular coagulation as demonstrated in experimental sepsis models, such as endotoxin-treated rabbits (26) and baboons exposed to Escherichia coli (27). In particular, TNF- $\alpha$ appears early in experimentally induced endotoxemia in humans $(28,29)$ and, hence, it might elicit a procoagulant response by endothelial cells. Endothelial cells express two TNF- $\alpha$ receptors, a 55- (TNFRp55) ${ }^{1}$ and a 75-kD (TNFR-p75) receptor $(30,31)$. It remained unknown whether one or both receptors is involved in inducing tissue factor on endothelial cells.

We showed previously that TNF- $\alpha$-stimulated endothelial cells initiate the deposition of fibrin on their surface when exposed to flowing native blood and that this was entirely dependent on the expression of tissue factor (32). This model uses human nonanticoagulated (native) blood (33) which, in contrast to citrated or heparin-treated blood, does not affect cation-dependent processes, such as blood coagulation, platelet adhesion, and platelet aggregation. This system was extended to investigate the effects of antithrombotics on endothelial cell-mediated deposition of fibrin and platelets at a shear rate of $65 \mathrm{~s}^{-1}$, which is typical for flow conditions in large veins. A special mixing device was used which allowed supplementation of the native blood with an antithrombotic compound under continuous flow conditions.

This report describes the effects of recombinant (rec.) hirudin (34), heparin, and the selective, reversible thrombin in-

1. Abbreviations used in this paper: FPA, fibrinopeptide A; HUVEC, human umbilical vein endothelial cells; $\mathrm{IC}_{50}, 50 \%$ inhibitory concentration; rec., recombinant; TNFR-p55, 55-kD TNF receptor; TNFR75, 75-kD TNF receptor; VCAM-1, vascular cell adhesion molecule-1. 
hibitor Ro 46-6240 in the blood flow system with TNF- $\alpha-$ stimulated endothelial cells. The results showed that all thrombin inhibitors reduced fibrin deposition in a concentration-dependent manner, albeit with different potency. The results demonstrated further that TNF- $\alpha$ induces heterogenous distribution of procoagulant activity on the endothelial monolayer, which may be related to the TNFR-p55-mediated heterogenous surface expression of tissue factor.

\section{Methods}

Culture of human umbilical vein endothelial cells (HUVEC). Endothelial cells were isolated from umbilical veins as described by Jaffe et al. (35) using a solution of $0.1 \%$ collagenase (CLI; Worthington Biochemical Corp., Freehold, NJ) in M199 (Sigma Immunochemicals, St. Louis, MO). The endothelial cells were grown in M199 supplemented with $10 \%$ newborn calf serum (GIBCO BRL, Basel, Switzerland), $10 \%$ FCS (GIBCO BRL), penicillin, streptomycin, glutamine (GIBCO $\mathrm{BRL}$ ), $50 \mu \mathrm{g} / \mathrm{ml}$ endothelial cell growth factor (Collaborative Research Inc., Bedford, MA), and $100 \mu \mathrm{g} / \mathrm{ml}$ heparin (Sigma Immunochemicals). Immunofluorescence staining showed that confluent cultures expressed the endothelial cell marker von Willebrand factor (polyclonal antiserum directed against Factor VIII-related antigen; DAKO A/S, Glostrup, Denmark) and did not express the vascular cell adhesion molecule-1 (VCAM-1) unless they were stimulated with TNF- $\alpha$ (monoclonal antibody against VCAM-1; British Bio-technology Products Ltd., Abingdon, UK).

Antibodies, proteins, and thrombin inhibitors. Monoclonal antifibrin antibody and monoclonal antitissue factor antibody (Nr. 4507) were from American Diagnostica Inc. (Greenwich, CT). Monoclonal antitissue factor antibody HTFI-7B8 was described by Carson et al. (36) and was produced by the Biotechnology Department, F. Hoffmann-La Roche Ltd., Basel, Switzerland. The control antibody was a monoclonal anti-GPIIb antibody (obtained from Dr. B. Steiner, Hoffmann-La Roche Ltd.). Recombinant desulfato hirudin "CGP 39393" (rec. hirudin) was a generous gift from Dr. R. B. Wallis (Ciba Pharmaceuticals, Horsham, UK). Unfractionated heparin (Liquemin) with an estimated average molecular weight of 15,000 was from Hoffmann-La Roche Ltd. The thrombin inhibitor Ro 46-6240 depicted in Fig. 1 is $N$ - $(N 4-[\{(S)$-1-amidino-3-piperidinyl $\}$ methyl]- $N 2$-[2-naphthalenesulfonyl]-L-asparaginyl)- $N$-cyclopropylglycine $\left(\mathrm{C}_{26} \mathrm{H}_{34} \mathrm{~N}_{6} \mathrm{O}_{6} \mathrm{~S}\right.$; mol wt 558.66) and was synthesized as described (Hilpert, K., J. Ackermann, D. W. Banner, A. Gast, K. Gubernator, P. Hadvary, L. Labler, K. Müller, G. Schmid, T. B. Tschopp, and H. van de Waterbeemd, manuscript in preparation ). Ro $46-6240$ is a specific, reversible inhibitor of thrombin with a $K_{\mathrm{i}}$ of $0.3 \mathrm{nM}$.

The two receptor-selective mutants of TNF- $\alpha$ were generously provided by Dr. H. Loetscher and Dr. W. Lesslauer (F. Hoffmann-La Roche Ltd.). The mutant selective for TNFR-p55 contained the two mutations $\mathrm{Arg}^{32}$-Trp and $\mathrm{Ser}^{86}-\mathrm{Thr}$ (double mutant R32W-S86T), and the one selective for TNFR-p75 had the two mutations Asp ${ }^{143}$-Asn and Ala ${ }^{145}$-Arg (double mutant D143N-A145R) (37). The selectivity of the mutants was demonstrated in a solid phase assay using recombinant human TNF receptors (37). The TNFR-p55-selective mutant R32W-S86T bound to TNFR-p55 similar to wild-type TNF- $\alpha$ but completely failed to bind to TNFR-p75. Conversely, the TNFR-p75-selective mutant D143N-A145R did not bind to TNFR-p55 but specifically<smiles>N=C(N)N1CCCC(CNC(=O)CN(CC(=O)O)C(=O)NCC(=O)OSc2ccc3ccccc3c2)C1</smiles>

Figure 1. Structure of Ro 46-6240.

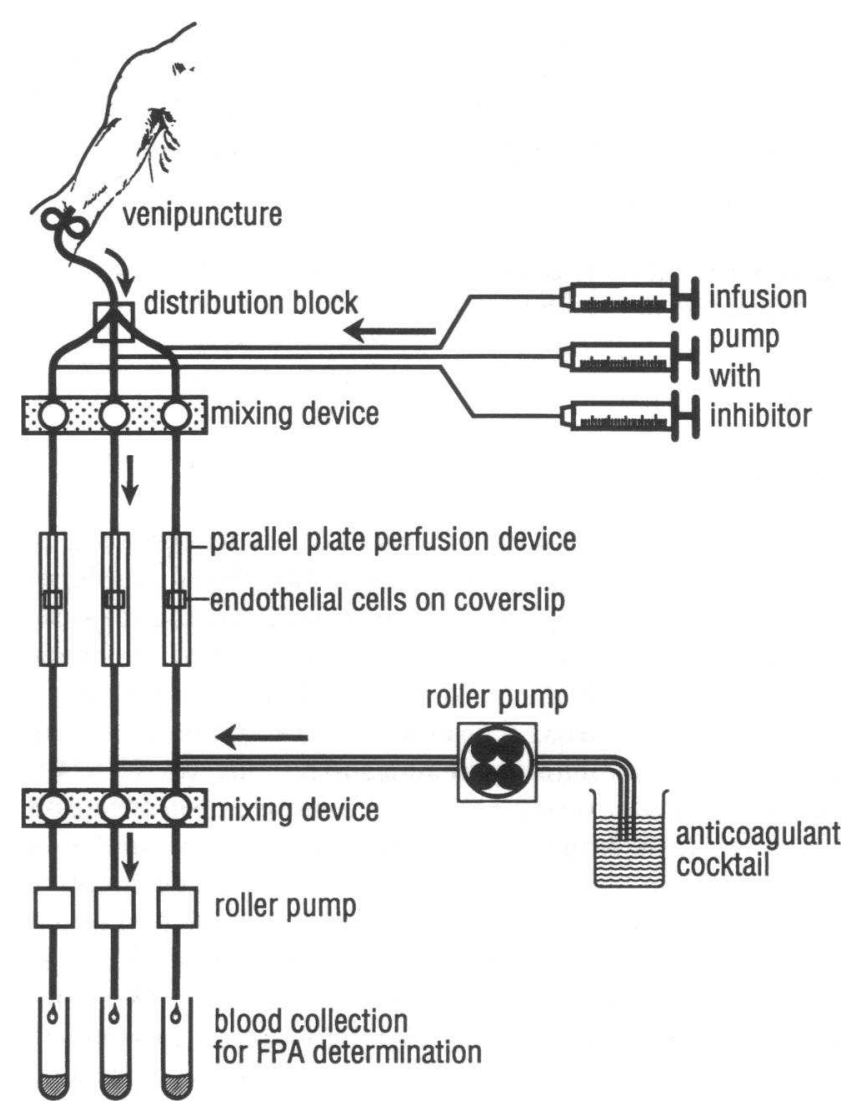

Figure 2. Experimental arrangement of the native blood perfusion system. Blood was drawn by venipuncture from the antecubital vein of a donor. A distribution block separated the blood into three tubings (a fourth tubing was connected to a roller pump as a safety measure and is omitted). Before entering the mixing device, the blood was supplemented with inhibitors by an infusion pump, and the components were mixed homogenously in three individual mixing chambers. The blood/inhibitor mixture then entered the perfusion devices containing the cover slips with the TNF- $\alpha$-stimulated endothelial cells. To stop further FPA generation, the blood leaving the perfusion devices was supplemented with an anticoagulant cocktail which was mixed with the blood (1:10) in a second mixing device. After passing through roller pumps, the blood was collected for FPA determinations.

bound to TNFR-p75, although with a 5-10-fold lower affinity than wild-type TNF- $\alpha$ (37).

Test of thrombin inhibitors in blood perfusion experiments using the mixing device. Endothelial cells at passage two or three were grown on gelatin-coated Thermanox plastic coverslips (Nunc, Inc., Naperville, IL) in 6-well cluster plates (Costar Corp., Cambridge, MA). Confluent cultures were incubated with 2.0 or $1.2 \mathrm{nM}$ TNF- $\alpha$ (Genzyme Corp., Cambridge, MA) in M199 containing 5\% newborn calf serum, 5\% FCS, $50 \mu \mathrm{g} / \mathrm{ml}$ endothelial cell growth factor, and $100 \mu \mathrm{g} / \mathrm{ml}$ heparin. After washing with M199/0.25\% BSA, three coverslips were positioned in three parallel plate perfusion chambers. The arrangement of the entire blood flow system is illustrated in Fig. 2. The whole system, including tubings, mixing chambers, and parallel plate devices, was filled with M199/1\% BSA. Then the blood was drawn from the antecubital vein of a healthy donor directly into a Plexiglas (Röhm Schweiz $\mathrm{GmbH}$, Brütisellen, Switzerland) distribution block where the blood was separated into four tubings. One tubing was connected to the accessory pump, serving as a safety measure in case of blood backflow (omitted in Fig. 2). In the remaining three tubings, the blood flowed in parallel at a rate of $1 \mathrm{ml} / \mathrm{min}$ into a mixing device consisting of three 
individual mixing chambers. The blood flow was controlled by three individual roller pumps positioned at the distal end of the parallel plate perfusion devices. Immediately before entering the mixing chambers, the flowing blood was supplemented with inhibitor solution at a rate of $50 \mu \mathrm{l} / \mathrm{min}$, resulting in a final concentration of $5 \%$ in the blood. The inhibitors dissolved in $0.9 \% \mathrm{NaCl} / 0.1 \% \mathrm{BSA}$ were supplied by three 1-ml glass syringes (Hamilton; Hamilton Bonaduz AG, Bonaduz, Switzerland) via an infusion pump (Infu 362; Datex AG, Switzerland). The inhibitors were mixed with the blood in the three mixing chambers, each containing a rotating magnetic stir bar (Fig. 3 ). The homogenous blood/inhibitor mixture then entered three parallel plate perfusion devices ( 3 ) containing the endothelial cell-coated coverslips. The blood flow of $1 \mathrm{ml} / \mathrm{min}$ resulted in a shear rate of $65 \mathrm{~s}^{-1}$ on the endothelial monolayer, which corresponded to venous blood flow conditions (4). The second mixing device at the outlet of the perfusion chambers (Fig. 2) was used only when additional fibrinopeptide A (FPA) determinations were carried out ( see below). For microdensitometrical measurements of fibrin and for morphometry, the blood flow was connected directly to the three roller pumps. After a 3.5-min perfusion period, the M199 wash solution reservoir was connected to the distribution block without interrupting the flow. During the 3-min washing period, the inhibitor infusion of $50 \mu \mathrm{l} / \mathrm{min}$ was maintained. Then the mixing device was disconnected from the parallel plate devices, which were subsequently perfused at $1 \mathrm{ml} / \mathrm{min}$ for $2 \mathrm{~min}$ with $3 \%$ paraformaldehyde in PBS (for immunochemical staining) after a brief interruption of flow ( $\sim 5 \mathrm{~s})$. For morphometrical examinations, the coverslips were perfused at $1 \mathrm{ml} / \mathrm{min}$ for $2 \mathrm{~min}$ with $2.5 \%$ glutaraldehyde in $0.1 \%$ cacodylate buffer, $\mathrm{pH} 7.4$, containing $2.5 \mathrm{mM} \mathrm{CaCl}_{2}$ and $0.9 \mathrm{mM} \mathrm{MgCl}_{2}$. Then the coverslips were removed from the chambers and incubated in fresh fixative for an additional $30 \mathrm{~min}$ and stored in PBS $/ 0.03 \%$ azide and in cacodylate buffer containing $7 \%$ sucrose for immunochemical staining and morphometrical analysis, respectively.

Mixing device. The device consisted of two removable Plexiglas blocks (Fig. 3, upper and lower blocks) containing the top and bottom parts of the three individual mixing chambers. Fig. 3 depicts a cross section through one of the three mixing chambers. The entrance on the bottom of the chamber was off-centered, which improved the mixing efficiency in the chamber. To reduce blood activation, the chamber was shaped so that the contact points between stir bar and chamber wall were minimal. The Teflon-covered stir bar (Semadeni AG, Ostermundigen, Switzerland) rotated at $360 \mathrm{rpm}$ and was driven by a mag-

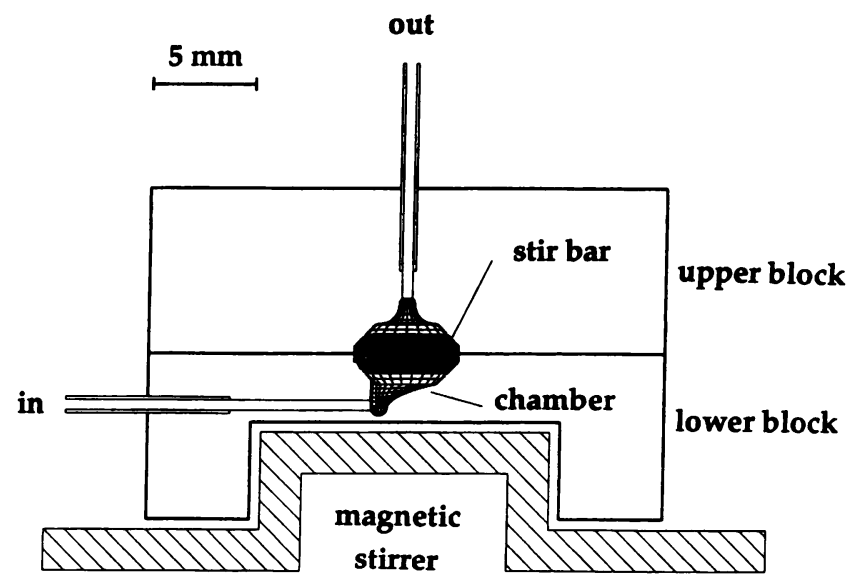

Figure 3. Dimensions of the mixing chamber. The mixing device (Fig. 2 ) contains three individual mixing chambers. Each mixing chamber (cross-hatched) consists of two parts, the top part embedded in the upper Plexiglas block and the bottom part in the lower block. The inlet to the mixing chamber is off-centered to improve mixing of the inhibitor solution with blood (1:20). The mixing was enhanced by stirring with a magnetic Teflon-covered stir bar (black) driven by a magnetic stirrer. netic stirrer (Fig. 3). The mixing device produced homogenous mixing as assessed by mixing a concentrated phenol red solution into human plasma flowing at $1 \mathrm{ml} / \mathrm{min}$ into the parallel plate perfusion device. The chamber volume was $37 \mathrm{~mm}^{3}$ (stir bar volume subtracted), which resulted in a turnover of 2.2 chamber volumes per second at a blood flow rate of $1 \mathrm{ml} / \mathrm{min}$.

Determination of FPA levels. FPA levels were measured in the blood leaving the perfusion device (postchamber). A second mixing device was positioned at the distal end of the parallel plate perfusion chambers (Fig. 2). This second mixing device served to mix the blood with an anticoagulant cocktail ( $32 \mathrm{mg} / \mathrm{ml}$ trisodium citrate, $1,000 \mathrm{IU} /$ $\mathrm{ml}$ heparin, and $1 \mathrm{TIU} / \mathrm{ml}$ aprotinin) to prevent further FPA generation. The anticoagulant cocktail was supplied by an additional roller pump at a flow rate of $0.1 \mathrm{ml} / \mathrm{min}$, resulting in a mixing ratio of $1: 10$ (anticoagulant cocktail/blood). The blood flow rate at the distal end of the mixing device was $1.1 \mathrm{ml} / \mathrm{min}$, which resulted in a blood flow rate of $1 \mathrm{ml} / \mathrm{min}$ (shear rate $65 \mathrm{~s}^{-1}$ ) over the endothelial cell layer consistent with the perfusion experiments described above. The anticoagulated blood was collected from the roller pumps into polypropylene tubes over a period of $2.5 \mathrm{~min}$. After centrifugation the platelet-poor plasma was stored at $-20^{\circ} \mathrm{C}$ until the FPA concentrations were determined according to the manufacturer's instructions (ELISA FPA; Boehringer Mannheim GmbH, Mannheim, Germany).

Immunogold-silver staining of tissue factor on the endothelial cell surface. Endothelial cells at passage one or two were grown on gelatincoated glass coverslips ( $11 \mathrm{~mm}$ in diameter) in 24-well plates (Falcon Multiwell, Becton Dickinson AG, Basel, Switzerland). Confluent cultures were stimulated with $2 \mathrm{nM} \mathrm{TNF}-\alpha$ for $4 \mathrm{~h}$ in M199 supplemented with $5 \%$ newborn calf serum, $5 \% \mathrm{FCS}, 50 \mu \mathrm{g} / \mathrm{ml}$ endothelial cell growth factor, $100 \mu \mathrm{g} / \mathrm{ml}$ heparin, glutamine, streptomycin, and penicillin. For experiments with mutated forms of TNF- $\alpha$, the monolayers were incubated for $4 \mathrm{~h}$ with $2 \mathrm{nM}$ (concentration of TNF- $\alpha$ monomer, mol wt 17,000) of the TNFR-p55-selective mutant or with a high concentration (100 nM) of the TNFR-p75-selective mutant to compensate for the lower binding activity of this mutant. Then the wells were washed two times with $\mathrm{M} 199 / 0.25 \%$ BSA and incubated for $30 \mathrm{~min}$ with $10 \mu \mathrm{g} / \mathrm{ml}$ of monoclonal antitissue factor antibody HTFI-7B8 or $10 \mu \mathrm{g} / \mathrm{ml}$ of control antibody (anti-GPIIb antibody). In some experiments $10 \mu \mathrm{g} / \mathrm{ml}$ of the antitissue factor antibody 4507 (American Diagnostica Inc.) was used. The wells were washed three times with PBS and fixed with 3\% paraformaldehyde in PBS for $10 \mathrm{~min}$. After washing with PBS, the coverslips were incubated in a humid chamber at $37^{\circ} \mathrm{C}$ with $5 \mathrm{~nm}$ immunogold conjugate (Auro Probe LM; Amersham International, Buckinghamshire, UK) diluted 1:20 in PBS. Then the wells were washed with PBS and incubated for 15 min with $2 \%$ glutaraldehyde in PBS. After washing with PBS and distilled water, the coverslips were incubated at room temperature with silver enhancer (IntenSE M; Amersham International). When tissue factor staining became visible (after 20-25 $\mathrm{min}$ ), the reaction was stopped by adding distilled water. It was assured that all appropriate controls such as nonstimulated cells and cells which received control antibody or were stimulated with TNF- $\alpha$ mutants were equally exposed to silver enhancer. The wells were washed with distilled water and incubated for $5 \mathrm{~min}$ with fixative (Rapidfix; Kodak, Rochester, NY). The coverslips were rinsed extensively in distilled water, dried overnight at room temperature, and then embedded in Merckoglas (E. Merck, Darmstadt, Germany). The endothelial cells were examined by epifluorescence and phase contrast on a microscope (Axiophot; Carl Zeiss AG, Zürich, Switzerland).

Quantification of platelets, fibrin, and leukocytes on semithin sections. After the perfusion experiments, the coverslips were embedded in Epon (Fluka Chemie, Buchs, Switzerland), and semithin sections perpendicular to the blood flow direction were prepared as described previously (38). The semithin sections were stained with $0.01 \%$ toluidine blue and $0.01 \%$ fuchsin, and the deposition of platelets, fibrin, and leukocytes along the length $(8 \mathrm{~mm})$ of the semithin section was determined morphometrically using a standard microscope (Carl Zeiss AG). Fibrin coverage was quantified by determining the presence or 
absence of fibrin at $10-\mu \mathrm{m}$ intervals along the cross section (38). This quantification method accurately reflects the amount of deposited fibrin as demonstrated by a parallel immunochemical quantification of fibrin, measuring fibrin fragment $\mathrm{E}$ after plasmin digestion (39). The platelet aggregates and leukocytes were quantified by counting their number along the cross section. Platelet aggregates were defined as three or more cohesive platelets which underwent shape change and were in contact with fibrin, the HUVEC surface, or leukocytes. The total number of leukocytes adhering to fibrin, platelets, or directly to the HUVEC surface was determined along the total length of the cross section $(8 \mathrm{~mm})$. Because the length of cross sections varied slightly between the specimens, the number of leukocytes and platelets was normalized to a standard length of $10 \mathrm{~mm}$.

Microdensitometry of immunogold-silver-stained fibrin. After the perfusion experiments, the coverslips were processed for microdensitometrical fibrin determination as described recently (32). Coverslips were incubated with monoclonal antifibrin antibody (American Diagnostica Inc.) at a concentration of $2.5 \mu \mathrm{g} / \mathrm{ml}$ in PBS followed by the secondary 5-nm gold-labeled anti-mouse antibody (Auro Probe LM; Amersham International) diluted 1:50 in PBS. The coverslips were treated for 10 min with $2 \%$ glutaraldehyde in PBS, washed in PBS and distilled water, and incubated with silver enhancer for $10 \mathrm{~min}$ (IntenSE M; Amersham International). The coverslips were fixed with Rapidfix (Kodak) and washed extensively in distilled water. After air drying, the coverslips were embedded in Merckoglass (E. Merck), and the relative optical density of the stained fibrin was determined with a computerized image analysis system (MCID program; Imaging Research Inc., Ontario, Canada) using a microscope (Axiophot; Carl Zeiss AG). The values were obtained from three measurements of areas of $1 \mathrm{~mm}^{2}$ in the center of the coverslip.

\section{Results}

Minimal activation of blood coagulation by the mixing device. The mixing device (Fig. 3 ) permitted a homogenous mixing of inhibitor with the flowing native blood. The activation of blood coagulation because of the mixing was assessed by measuring the FPA levels in the blood leaving the mixing device. The average FPA levels from the blood of five donors was $6.8 \pm 0.8$ $\mathrm{ng} / \mathrm{ml}( \pm \mathrm{SEM})$. The activation of blood during the passage through the entire perfusion system consisting of mixing device and perfusion chamber with uncoated cover slip (Fig. 2) was $8.6 \pm 4.1 \mathrm{ng} / \mathrm{ml}$ ( $\pm \mathrm{SEM}$; four donors $)$. In accordance with this relatively low activation, no fibrin was detected on uncoated cover slips by fibrin-specific immunogold-silver staining.

Inhibition of fibrin deposition on endothelial cells by thrombin inhibitors. Before the perfusion experiments, the endothelial cells were stimulated for $4 \mathrm{~h}$ with $2 \mathrm{nM} \mathrm{TNF}-\alpha$. This led to endothelial cell expression of tissue factor, resulting in fibrin deposition in the native blood flow system. To study the effect of the three thrombin inhibitors on fibrin deposition, the substances were infused into the flowing blood at a ratio of $1: 20$ by the mixing device before the blood entered the parallel plate perfusion devices containing the stimulated endothelial cells (Fig. 2). Controls received $0.9 \% \mathrm{NaCl}$ solution containing $0.1 \%$ BSA instead of inhibitor. We found that all three substances inhibited fibrin deposition on the endothelial cell monolayer in a concentration-dependent manner as determined by microdensitometry of immunogold-silver-stained fibrin (Fig. 4). As expected, rec. hirudin was more potent than Ro 46-6240 and heparin (Fig. 4, inset). On a weight basis, Ro 46-6240 ( $50 \%$ inhibitory concentration $\left[\mathrm{IC}_{50}\right]$ of $\sim 28 \mathrm{ng} / \mathrm{ml}$ ) was almost as active as rec. hirudin $\left(\mathrm{IC}_{50}\right.$ of $\sim 14 \mathrm{ng} / \mathrm{ml}$ ) and $\sim 14$ fold more active than heparin ( $\mathrm{IC}_{50}$ of $\sim 400 \mathrm{ng} / \mathrm{ml}$ ). Complete inhibition of fibrin deposition was achieved at $560 \mathrm{ng} / \mathrm{ml}$

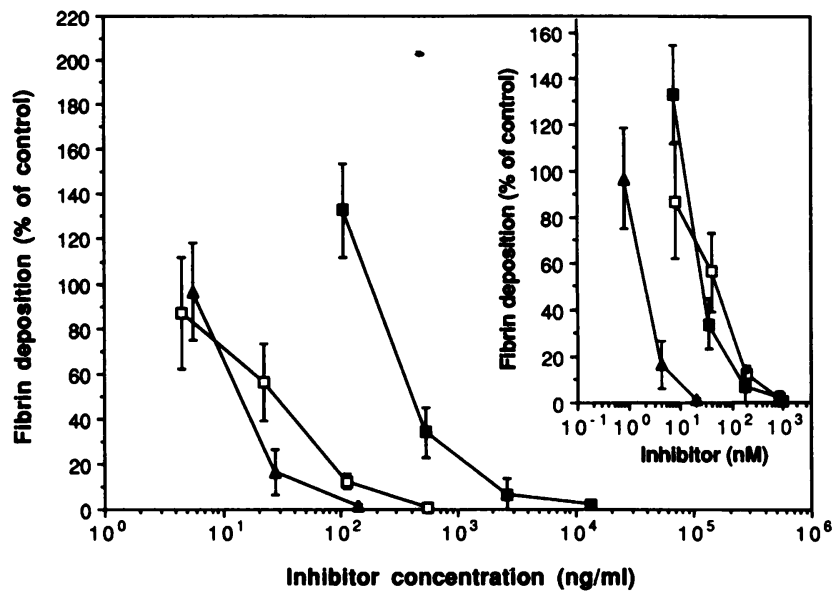

Figure 4. Inhibition of fibrin deposition on TNF- $\alpha$-stimulated endothelial cells by three thrombin inhibitors. The thrombin inhibitors Ro 46-6240 (open squares), rec. hirudin (closed triangles), and heparin (closed squares) at increasing concentrations were infused into flowing native human blood. Fibrin deposition on tissue factor-expressing endothelial cells was quantified by microdensitometry of fibrin stained by the immunogold-silver method using a fibrin-specific antibody. The values represent the means \pm SEM of four to seven measurements and are expressed as a percentage of the fibrin deposited on TNF- $\alpha$-stimulated endothelial cells in the absence of inhibitor ( $=100 \% ; 17$ measurements). The inset shows the same inhibition curves expressed in molar inhibitor concentrations.

Ro 46-6240, $140 \mathrm{ng} / \mathrm{ml} \mathrm{rec}$. hirudin, and 13,300 ng/ml heparin (Fig. 4).

Effect of thrombin inhibitors on the blood FPA levels. Exposure of endothelial cells stimulated with $1.2 \mathrm{nM}$ TNF- $\alpha$ to native blood resulted in similar postchamber FPA levels as compared with stimulation with 2 nM TNF- $\alpha$ (data not shown). Therefore, for this and the following perfusion experiments, endothelial cells were stimulated with only $1.2 \mathrm{nM}$ TNF- $\alpha$ instead of the previously used 2 nM TNF- $\alpha$. For FPA measurements, the inhibitors were tested at concentrations that almost completely inhibited fibrin deposition as measured by the microdensitometry method. Upon perfusion TNF- $\alpha$-stimulated endothelial cells produced FPA levels of $713 \mathrm{ng} / \mathrm{ml}$, whereas nonstimulated cells generated only $21 \mathrm{ng} / \mathrm{ml}$ (Fig. 5). Ro 466240 at $560 \mathrm{ng} / \mathrm{ml}$ reduced the FPA levels to $31 \mathrm{ng} / \mathrm{ml}$ which corresponded to an inhibition of $95 \%$ (Fig. 5). Similarly, rec. hirudin at $140 \mathrm{ng} / \mathrm{ml}$ and heparin at $13,300 \mathrm{ng} / \mathrm{ml}$ strongly reduced the FPA generation to 66 and $50 \mathrm{ng} / \mathrm{ml}$, respectively.

Morphometrical analysis of fibrin, platelets, and leukocytes on endothelial cell semithin sections. After the perfusion experiments, the cover slips with the endothelial cells were embedded in Epon, and semithin sections were analyzed for deposited fibrin, platelets, and leukocytes. As shown in Fig. $6 a$, all inhibitors reduced fibrin coverage from $71 \%$ to $<3 \%$. Fibrin deposition on nonstimulated endothelial cells was $<5 \%$. Similarly, the deposition of platelet aggregates decreased from 50 per cross section to $<4$ per cross section in the presence of the inhibitors (Fig. $6 b$ ). In contrast, leukocyte deposition was unaffected by the inhibitors (Fig. $6 c$ ). Representative cross sections in Fig. 7 illustrate that, in the presence of inhibitors, leukocytes adhered directly to the endothelial cell layer. In comparison, the surface of nonstimulated endothelial cells was free of thrombus constituents (Fig. $7 a$ ), whereas TNF- $\alpha$-stimu- 


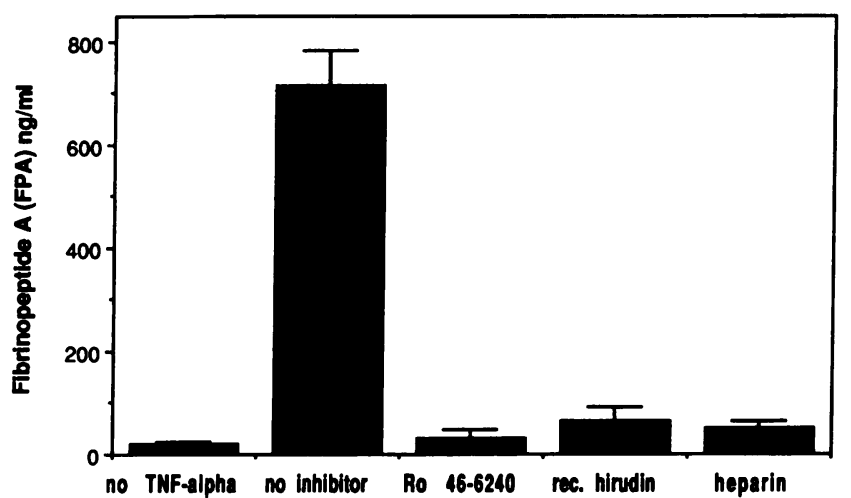

Figure 5. Effect of thrombin inhibition on FPA levels. Ro 46-6240 at $560 \mathrm{ng} / \mathrm{ml}$, rec. hirudin at $140 \mathrm{ng} / \mathrm{ml}$, and heparin at $13,300 \mathrm{ng} / \mathrm{ml}$ were infused into flowing native blood. After leaving the perfusion devices with the TNF- $\alpha$-stimulated endothelial cells, the blood was mixed with an anticoagulant cocktail by means of a second mixing device (Fig. 2). The blood for FPA determinations was collected over a period of $2.5 \mathrm{~min}$. Controls were TNF- $\alpha$-stimulated endothelial cells (no inhibitor) and nonstimulated cells (no TNF- $\alpha$ ) which were exposed to blood supplemented with $0.9 \% \mathrm{NaCl} / 0.1 \%$ BSA solution instead of inhibitor. Values represent the means \pm SEM of 6-17 measurements.

lated control cells were covered with fibrin, platelets, leukocytes, and red blood cells (Fig. $7 b$ ).

Focal deposition of fibrin on endothelial cells at high inhibitor concentrations. Microscopical examination revealed that increasing concentrations of Ro 46-6240 reduced the fibrin deposition on endothelial cells almost completely. However, some residual fibrin formed locally, covering a few endothelial cells and apparently even single cells (Fig. 8, $c$ and $d$ ). This focal fibrin deposition may be related to the local fibrin accumulation seen on TNF- $\alpha$-stimulated endothelial cells in the absence of inhibitor (Fig. $8 b$ ). Fig. 8, $e$ and $f$ further illustrate single or several TNF- $\alpha$-stimulated endothelial cells covered with stained fibrin fibers formed in the presence of the highest concentration of Ro 46-6240 (560 ng/ml). Similar results were obtained with the highest concentrations of rec. hirudin and heparin (data not shown). These results suggested that TNF$\alpha$-stimulated endothelial cells express varying procoagulant activity.

$T N F-\alpha-$-induced surface expression and distribution of tissue factor on endothelial cells. To examine whether this inhomogenous distribution of procoagulant activity was related to the local density of endothelial tissue factor, we analyzed the surface expression of tissue factor by immunogold-silver staining. Fig. 9 shows the expression pattern of tissue factor on the surface of TNF- $\alpha$-stimulated endothelial cells. The amount of tissue factor expressed by each cell varied strongly (Fig. 9, $c$ and d). Tissue factor was not detectable on nonstimulated cells (Fig. 9, $a$ and $b$ ), which agrees with the findings from the perfusion experiments demonstrating that fibrin deposition was virtually absent on nonstimulated endothelial cells (Fig. $8 a$ ). Microscopical examination of TNF- $\alpha$-stimulated endothelial cells by phase contrast combined with epifluorescence at a higher magnification more clearly visualizes the localization of tissue factor on each single cell (Fig. $9 g$ ). Similar results were obtained when another monoclonal antitissue factor antibody was used (monoclonal antibody 4507; American Diagnostica Inc.) (data not shown). The staining was specific since a con- trol antibody did not produce any staining on TNF- $\alpha$-stimulated cells (Fig. 9, $e$ and $f$ ). Since we used a pool of endothelial cells from several umbilical cords, the inhomogenous tissue factor expression might have reflected variations of the different cord sources. Therefore, endothelial cells were isolated from single umbilical cords and examined at passage one in two separate experiments. Similar to the experiments with endothelial cells from pooled cords, we found varying degrees of tissue factor expression (data not shown).

Because human endothelial cells have two types of TNF- $\alpha$ receptors (30), TNFR-p55 and TNFR-p75, we examined whether both receptors were involved in the TNF- $\alpha$-depen-

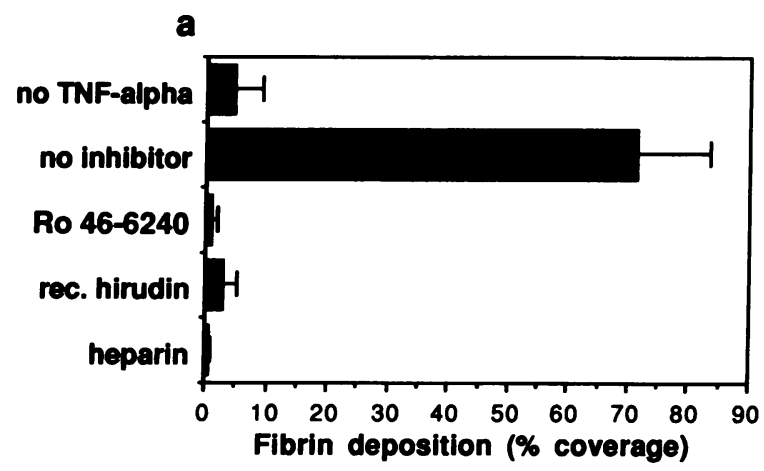

b

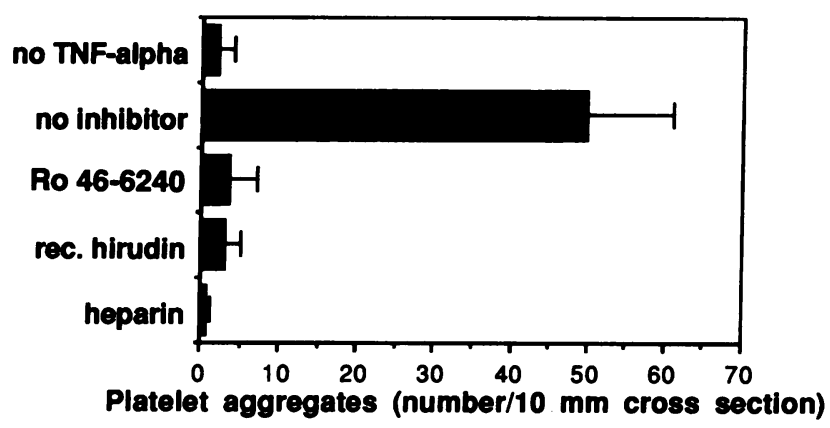

C

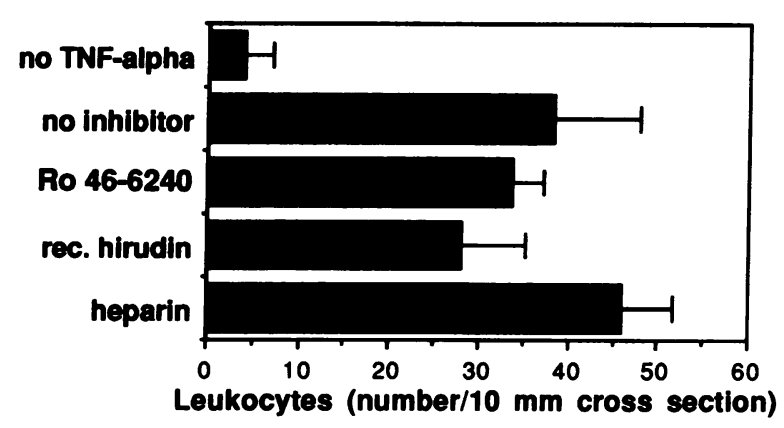

Figure 6. Quantification of fibrin, platelets, and leukocytes deposited on TNF- $\alpha$-stimulated endothelial cells. After exposure to flowing native human blood supplemented with either Ro 46-6240 (560 ng/ $\mathrm{ml})$, rec. hirudin $(140 \mathrm{ng} / \mathrm{ml})$, or heparin $(13,300 \mathrm{ng} / \mathrm{ml})$, the endothelial cell-covered coverslips were processed for morphometrical analysis as described in Methods. Cross sections were stained with fuchsin/toluidine blue. ( $a$ ) Fibrin deposition, $(b)$ platelet aggregates, and $(c)$ leukocytes were determined along the length of the cross sections. Controls were TNF- $\alpha$-stimulated endothelial cells ( $n o$ inhibitor) and nonstimulated cells (no $T N F-\alpha$ ) which were exposed to $0.9 \%$ $\mathrm{NaCl} / 0.1 \%$ BSA solution instead of inhibitor. Values are the means \pm SEM of four to seven individual cover slips. 

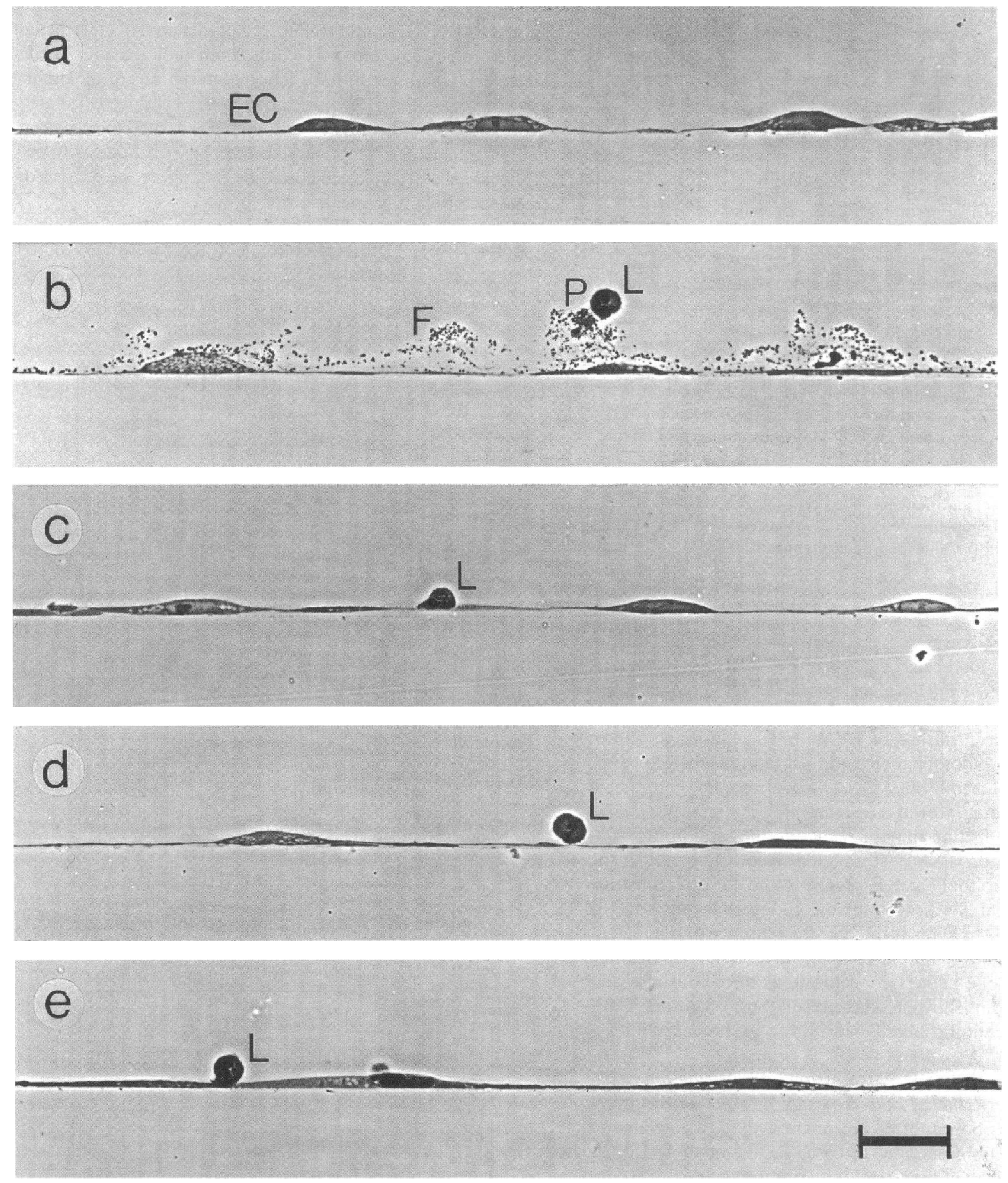

Figure 7. Deposition of fibrin, platelets, and leukocytes on TNF- $\alpha$-stimulated endothelial cells after exposure to inhibitor-supplemented flowing native blood. Shown are representative cross sections of specimens from experiments shown in Fig. 6. $(a)$ Nonstimulated endothelial cells; $(b)$ TNF- $\alpha$-stimulated endothelial cells in the absence of inhibitor or in the presence of $(c) 560 \mathrm{ng} / \mathrm{ml} \mathrm{Ro} \mathrm{46-6240,(d)} 140 \mathrm{ng} / \mathrm{ml} \mathrm{rec}$. hirudin, and (e) $13,300 \mathrm{ng} / \mathrm{ml}$ heparin. $E C$, endothelial cells; $F$, fibrin; $L$, leukocytes; $P$, platelets. Bar $=20 \mu \mathrm{m}$.

dent heterogenous surface expression of tissue factor. To activate only one of the two receptors, we used mutated forms of human TNF- $\alpha$ with high selectivity for one receptor subtype (37). Endothelial cells at first passage derived from a single cord were incubated with $2 \mathrm{nM}$ of the TNFR-p55-selective mutant. This resulted in the upregulation of tissue factor which was detected by immunogold-silver staining using the tissue factor antibody HTFI-7B8 (Fig. 10 $a$ ). The surface expression was heterogenous and similar to the experiments with wildtype TNF- $\alpha$ (Fig. $9 c$ ). In contrast, stimulation even with a high concentration ( $100 \mathrm{nM}$ ) of the TNFR-p75-selective mutant did not lead to any detectable surface expression of tissue factor (Fig. $10 \mathrm{~b}$ ), similar to the result with nonstimulated endothelial cells (Fig. $10 \mathrm{c}$ ). The same results were obtained 

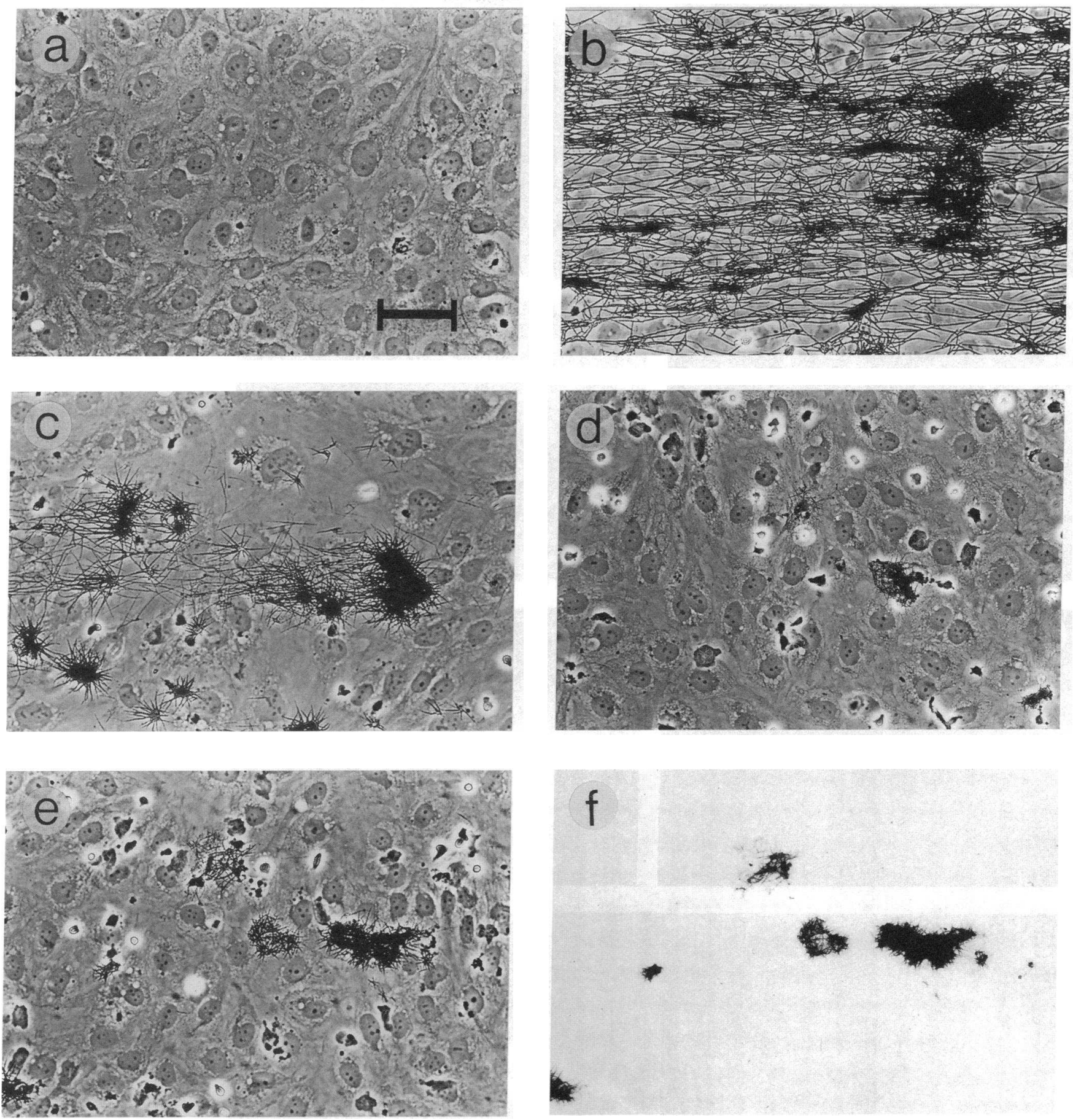

Figure 8. Micrographs showing the focal fibrin deposition on TNF- $\alpha$-stimulated endothelial cells. After exposure to flowing native blood (on the micrographs the flow direction was right to left) containing increasing concentrations of Ro 46-6240, the fibrin deposited on endothelial cells was stained using a monoclonal fibrin-specific antibody and subsequent immunogold-silver staining. $(a)$ Nonstimulated endothelial cells; $(b)$ TNF- $\alpha$-stimulated cells in the absence of inhibitor or in the presence of $(c) 110 \mathrm{ng} / \mathrm{ml} \mathrm{Ro} \mathrm{46-6240} \mathrm{and}(d) 560 \mathrm{ng} / \mathrm{ml} \mathrm{Ro} \mathrm{46-6240.} \mathrm{(e)} \mathrm{Phase}$ contrast of several fibrin deposits on stimulated endothelial cells in the presence of $560 \mathrm{ng} / \mathrm{ml} \mathrm{Ro} 46-6240$ and $(f)$ corresponding bright-field which shows stained fibrin only. Bar $=50 \mu \mathrm{m}$.

when endothelial cells pooled from several umbilical cords were used (data not shown).

\section{Discussion}

This report describes the inhibitory effects of three different thrombin inhibitors in a human native blood flow system which uses TNF- $\alpha$-stimulated human endothelial cells as a coagulation-promoting surface. All thrombin inhibitors reduced fibrin deposition on the endothelial cell surface, although with different potencies. Furthermore, even at inhibitor concentrations that strongly reduced postchamber FPA levels, some fibrin deposition occurred locally, apparently on the surface of single or several adjacent endothelial cells. Examination 

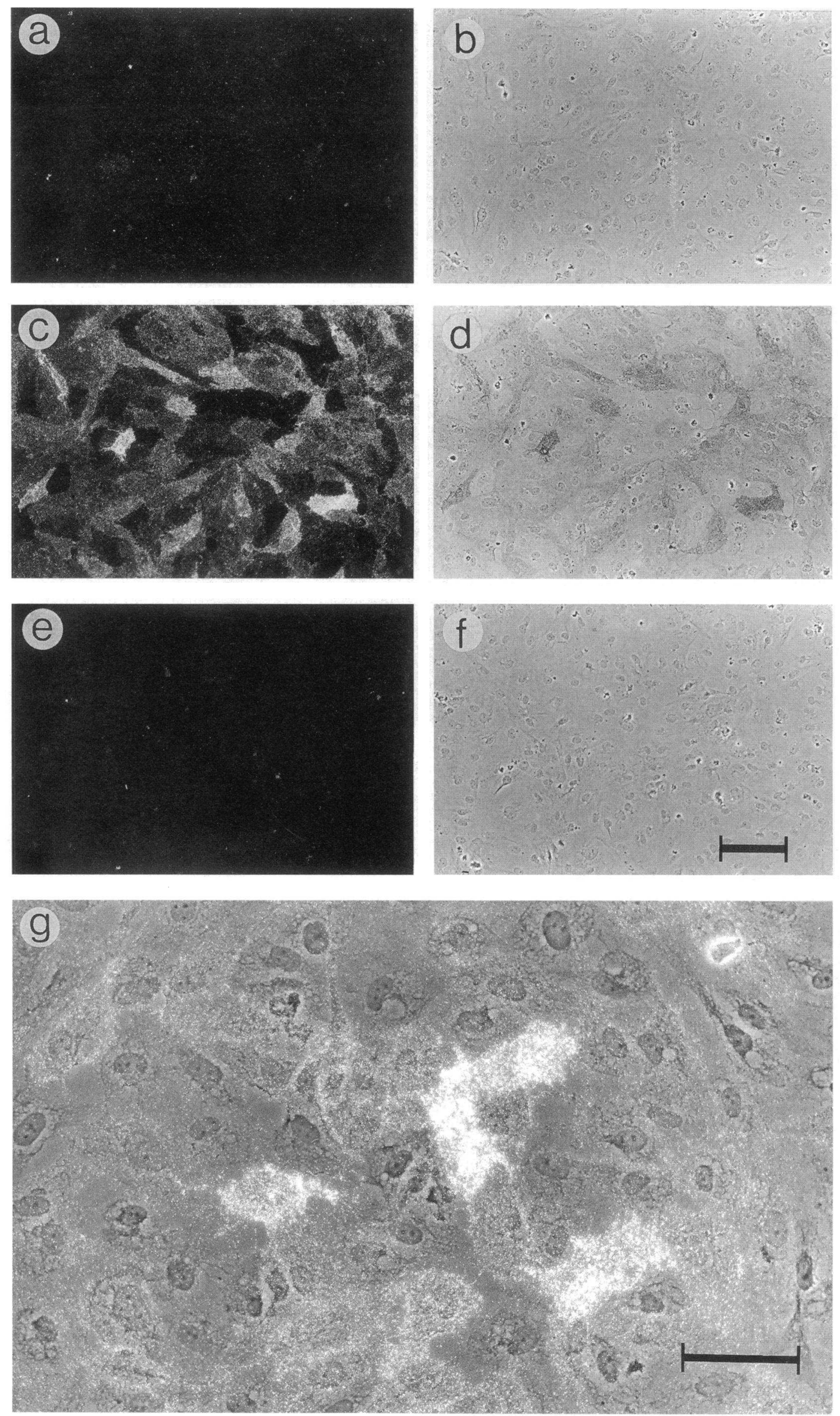
of tissue factor expression using wild-type and mutated TNF- $\alpha$ forms suggested a relationship between the focal fibrin deposition and high local tissue factor density on the endothelial surface.

The use of native blood in the experimental flow system averted interference with the coagulation system that occurs when using citrated or heparinized blood. This was particularly important for examining the anticoagulant activity of thrombin inhibitors. To supplement the native blood with inhibitor, a mixing device was developed which produced a homogenous blood/inhibitor mixture under steady flow conditions. The activation of the coagulation system in the mixing device as assessed by the FPA levels was $<1 \%$ of peak FPA levels observed with stimulated endothelial cells and did not result in any detectable fibrin deposition on uncoated cover slips.

At a shear rate of $65 \mathrm{~s}^{-1}$, representing flow conditions in veins, the three thrombin inhibitors Ro 46-6240, rec. hirudin, and heparin inhibited fibrin formation, as assessed by FPA levels, by fibrin coverage determined on cross sections, and by density measurements after fibrin staining. On a molar basis rec. hirudin, as expected, was the most potent inhibitor. However, because of its low molecular weight, Ro 46-6240 was almost as active as rec. hirudin when the $\mathrm{IC}_{50}$ values were compared on a clinically relevant weight basis. In addition to their inhibitory effect on fibrin formation, Ro 46-6240, rec. hirudin, and heparin also inhibited deposition of platelet aggregates on the endothelial surface. This was most likely because of inhibition of the thrombin-mediated deposition of fibrin, the adhesive surface required for platelet deposition. In support of a fibrin-dependent platelet adhesion, we found that only $\sim 5 \%$ of all platelet aggregates were in direct contact with the endothelial cells by a possible fibrin-independent mechanism. In contrast to the effect on fibrin and platelets, the thrombin inhibitors failed to prevent leukocyte adhesion. This agrees well with the findings from a similar blood flow system showing that leukocyte adhesion to TNF- $\alpha$-stimulated endothelial cells persisted despite complete inhibition of endothelial cell-mediated coagulation using antitissue factor antibody (32). Leukocytes that adhered to the endothelial surface independent of thrombin and fibrin most likely interacted directly with upregulated leukocyte adhesion receptors on the endothelial surface (40-43).

The fibrin deposited on TNF- $\alpha$-stimulated endothelial cells consisted of a fiber network and small and large fibrin accumulations (Fig. $8 b$ ). It was unclear why fibrin was deposited in such an irregular pattern. We hypothesized that some endothelial cells may express more procoagulant activity than others. In support of this we found residual fibrin that was deposited focally on stimulated endothelial cells in the presence of high concentration of thrombin inhibitors (Fig. 8, $e$ and $f$ ). Although visible by microscopical examination, this residual fibrin remained virtually nondetectable by the fibrin quantification methods used. At an intermediate inhibitor concentration, the number and size of fibrin deposits increased (Fig. 8 $c$ ), suggesting that these fibrin deposits may be related to the dense fibrin accumulations that were found in the absence of inhibitor. Because tissue factor was the primary initiator of the coagulation process in this experimental system, we examined whether this apparently inhomogenous distribution of procoagulant activity on the endothelial surface was related to tissue factor distribution. Immunogold-silver staining of TNF- $\alpha-$ stimulated cells showed that the amount of surface-expressed tissue factor varied strongly from cell to cell, resulting in a heterogenous distribution pattern on the endothelial monolayer. This agrees well with the observed tissue factor heterogeneity in endotoxin-treated endothelial cells (27), although that study (27) did not specify whether tissue factor was expressed on the cell surface. That our finding of a heterogenous endothelial surface expression of tissue factor may have physiological relevance is suggested by the finding of Drake et al. (27), demonstrating that tissue factor is heterogenously expressed in vascular beds of baboons exposed to $E$. coli. Although the reason for heterogeneity remains unclear, the results suggest that the varying degree of tissue factor expression may result in an inhomogenous procoagulant surface, leading to focal fibrin deposition in the native blood flow system.

In addition, since endothelial cells express two types of receptors for TNF- $\alpha$, TNFR-p55 and TNFR-p75 (30), it was important to find out whether both receptor types were involved in the heterogenous expression of tissue factor. Receptor-specific mutants of TNF- $\alpha$ were used to separately stimulate the receptor subtypes on the endothelial cells. The results clearly showed that tissue factor expression is regulated exclusively by TNFR-p55. Further, selective activation of TNFRp55 led also to a heterogenous tissue factor distribution on the endothelial surface. In contrast, the TNFR-p75-selective mutant did not lead to any detectable expression of tissue factor, even when used at high concentrations to compensate for the slightly lower affinity of this mutant for TNFR-p75 (37). The finding of a TNFR-p55-dependent upregulation of tissue factor agrees well with the function of this receptor on endothelial cells to induce expression of leukocyte adhesion receptors, such as E-selectin, intracellular adhesion molecule-1, and VCAM-1 $(30,31)$. Thus, it appears that molecules that may play an important role in inflammation and disseminated intravascular coagulation are all regulated by TNFR-p55.

Therefore, a possible explanation for the heterogenous tissue factor distribution may be that TNFR-p55 is distributed heterogenously over the endothelial cell layer. In addition, individual cells could have been in different phases of the cell cycle, which might affect tissue factor expression as suggested by Andoh et al. (44). Alternatively, independent of tissue factor expression, the endothelial cells might show variable procoagulant activity because they differ in the number or in the activity of their binding sites for the coagulation Factors IX and X (45-47).

The tissue factor staining was localized on the apical surface

Figure 9. TNF- $\alpha$-induced surface expression of tissue factor on endothelial cells. Confluent endothelial cells were incubated with or without 2 nM TNF- $\alpha$ for $4 \mathrm{~h}$. Tissue factor was visualized by immunogold-silver staining using the monoclonal antitissue factor antibody HTF1-7B8. The left panels of micrographs show the cell monolayer in epifluorescence (stained cells appear white), and the right panels show the corresponding field in phase contrast (stained cells appear dark). ( $a$ and $b$ ) Nonstimulated cells plus $10 \mu \mathrm{g} / \mathrm{ml}$ HTF1-7B8, ( $c$ and $d)$ TNF- $\alpha-$ stimulated cells plus $10 \mu \mathrm{g} / \mathrm{ml} \mathrm{HTF1-7B8,}(e$ and $f$ ) TNF- $\alpha$-stimulated cells plus $10 \mu \mathrm{g} / \mathrm{ml}$ control antibody (anti-GPIIb), and $(g)$ density of tissue factor (stained as in $c$ and $d$ ) on stimulated endothelial cells at higher magnification combining epifluorescence and phase contrast. Small bar $=100 \mu \mathrm{m}(a-f) ;$ large bar $=50 \mu \mathrm{m}(g)$. 

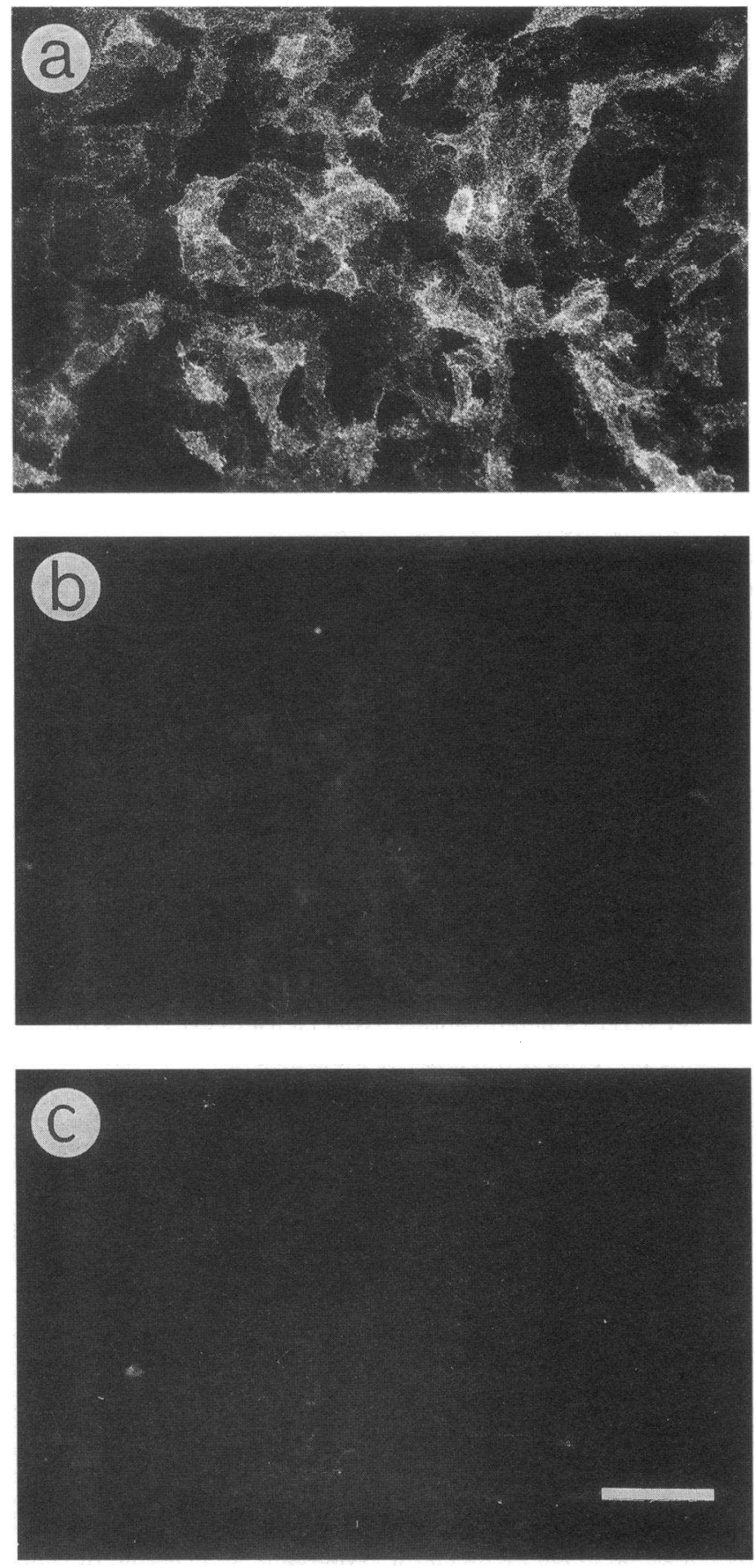

Figure 10. Tissue factor expression after selective stimulation of TNFR-p55 or TNFR-p75. Confluent endothelial cells (passage one) derived from a single umbilical cord were stimulated for $4 \mathrm{~h}$ with $(a)$ $2 \mathrm{nM}$ of the TNFR-p55-selective TNF mutant (double mutant R32W-S86T), ( $b$ ) $100 \mathrm{nM}$ of the TNFR-p75-selective mutant (double mutant D143N-A145R), or (c) nonstimulated cells. Tissue factor was detected by immunogold-silver staining as in Fig. 9. The endothelial monolayers are shown with epifluorescence, and stained cells appear white. The antibody was monoclonal antitissue factor antibody HTF1-7B8 $(10 \mu \mathrm{g} / \mathrm{ml}) . \mathrm{Bar}=100 \mu \mathrm{m}$.

of the endothelial cells and appears to contrast the reported absence of apical tissue factor on stimulated endothelial cells (48). However, in agreement with this report we also found a very low Factor $\mathrm{X}$ activation rate in the presence of Factor VIIa and calcium by TNF- $\alpha$-stimulated endothelial monolayers as compared with J82 carcinoma cells and WI38 fibroblasts (D. Kirchhofer, unpublished observation ). Nevertheless, this relatively low tissue factor activity of TNF- $\alpha$-stimulated endothelial cells was sufficient to initiate coagulation in the native blood flow system resulting in the deposition of fibrin. Therefore, the different sensitivities of the staining methods might account for the disparate results regarding tissue factor localization on the apical side of the endothelial monolayer. Findings from a different endothelial flow system also indicated a surface localization of tissue factor and showed that tissue factor function may also be regulated by the presence of tissue factor pathway inhibitor on the cell surface (12).

In conclusion, our results suggest that the TNFR-p55-induced heterogenous surface expression of tissue factor may be linked to the observed heterogenous fibrin deposition on endothelial cells. When exposed to flowing native blood, areas on the endothelial monolayer with high tissue factor density might generate high local concentrations of thrombin. Despite the presence of thrombin inhibitors at concentrations which significantly inhibit FPA generation, local fibrin deposition may occur. The results further showed a better activity of Ro 46-6240 in inhibiting fibrin deposition as compared with heparin. Together with the finding that it also inhibits clot-bound thrombin more potently than heparin (Gast, A., T. B. Tschopp, G. Schmid, K. Hilpert, and J. Ackermann, manuscript submitted for publication ), Ro 46-6240 may show improved antithrombotic activity in vivo as compared with heparin, which is commonly used to treat venous thrombosis. In addition to the experiments with endothelial cells, this experimental blood flow system has broad applications in studying thrombotic processes. Dependent on the chosen thrombogenic surface and the shear rate, it permits one to investigate thrombotic processes under venous and arterial flow conditions in the presence of a given substance. Such studies may further elucidate processes that lead to thrombus formation under physiological and pathological conditions.

\section{Acknowledgments}

We thank Isabelle Guillaumat, Olivier Kuster, and Hildegund Mösch for their excellent technical assistance and Alfred Witschi for constructing the mixing devices. We further wish to thank Dr. Hansruedi Loetscher and Dr. Werner Lesslauer for the TNF- $\alpha$ mutants; Dr. Bob Wallis for the rec. hirudin; and Georg Schmid for supplying the HTF17B8 antibody.

\section{References}

1. Baumgartner, H. R., V. Turitto, and H. J. Weiss. 1980. Effect of shear rate on platelet interaction with subendothelium in citrated and native blood. J. Lab. Clin. Med. 95:208-221.

2. Baumgartner, H. R., and K. S. Sakariassen. 1985. Factors controlling thrombus formation on arterial lesions. Ann. NY Acad. Sci. 454:162-177.

3. Sakariassen, K. S., R. Joss, R. Muggli, H. Kuhn, T. B. Tschopp, H. Sage, and H. R. Baumgartner. 1990. Collagen type III induces ex vivo thrombogenesis in humans. Arteriosclerosis. 10:276-284.

4. Turitto, V. T., and H. R. Baumgartner. 1987. Platelet-surface interactions. In Haemostasis and Thrombosis. 2nd ed. R. W. Colman, J. Hirsh, V. J. Marder, and E. W. Salzman, editors. 555-571.

5. Weiss, H. J., V. T. Turitto, and H. R. Baumgartner. 1986. Role of shear rate and platelets in promoting fibrin formation on rabbit subendothelium. Studies utilizing patients with quantitative and qualitative platelet defects. J. Clin. Invest. 78:1072-1082.

6. Zwaginga, J. J., H. C. de Boer, M. J. W. Ijsseldijk, A. Kerkhof, G. MullerBerghaus, J. Gruhlichhenn, J. J. Sixma, and P. G. de Groot. 1990. Thrombogenicity of vascular cells. Arteriosclerosis. 10:437-448. 
7. Zwaginga, J. J., J. J. Sixma, and P. G. de Groot. 1990. Activation of endothelial cells induces platelet thrombus formation on their matrix. Arteriosclerosis. 10:49-61.

8. Tijburg, P. N. M., M. J. W. Ijsseldijk, J. J. Sixma, and P. G. de Groot. 1991. Quantification of fibrin deposition in flowing blood with peroxidase-labelled fibrinogen. Arterioscler. Thromb. 11:211-220.

9. Gemmell, C. H., Y. Nemerson, and V. Turitto. 1990. The effects of shear rate on the enzymatic activity of the tissue factor-factor VIIa complex. Microvasc. Res. 40:327-340.

10. Repke, D., C. H. Gemmell, A. Guha, V. T. Turitto, G. J. Broze, Jr., and Y. Nemerson. 1990. Hemophilia as a defect of the tissue factor pathway of blood coagulation: effect of factors VIII and IX on factor X activation in a continuousflow reactor. Proc. Natl. Acad. Sci. USA. 87:7623-7627.

11. Nemerson, Y., and V. T. Turitto. 1991. The effect of flow on hemostasis and thrombosis. Thromb. Haemostasis. 66:272-276.

12. Grabowski, E. F., D. B. Zuckerman, and Y. Nemerson. 1993. The functional expression of tissue factor by fibroblasts and endothelial cells under flow conditions. Blood. 81:3265-3270.

13. Marcum, J. A., and R. D. Rosenberg. 1984. Anticoagulantly active heparin-like molecules from vascular tissue. Biochemistry. 23:1730-1737.

14. Marcum, J. A., D. H. Atha, L. M. S. Fritze, P. Nawroth, D. Stern, and R. D. Rosenberg. 1986. Cloned bovine aortic endothelial cells synthesize anticoagulantly active heparan sulfate proteoglycan. J. Biol. Chem. 261:7507-7517.

15. Esmon, N. L., W. G. Owen, and C. T. Esmon. 1982. Isolation of a membrane-bound cofactor for thrombin-catalyzed activation of protein C. J. Biol Chem. 257:859-864.

16. Esmon, C. T. 1987. The regulation of natural anticoagulant pathways. Science (Wash. DC). 235:1348-1352.

17. Loskutoff, D. J., and T. S. Edgington. 1977. Synthesis of a fibrinolytic activator and inhibitor by endothelial cells. Proc. Natl. Acad. Sci. USA. 74:39033907.

18. Weksler, B. B., A. J. Marcus, and E. A. Jaffe. 1977. Synthesis of prostaglandin $\mathrm{I}_{2}$ ( prostacyclin) by cultured human and bovine endothelial cells. Proc. Natl. Acad. Sci. USA. 74:3922-3926.

19. Bevilacqua, M. P., J. S. Pober, G. R. Majeau, W. Fiers, R. S. Cotran, and M. A. Gimbrone, Jr. 1986. Recombinant tumor necrosis factor induces procoagulant activity in cultured human vascular endothelium: characterization and comparison with the actions of interleukin 1. Proc. Natl. Acad. Sci. USA. 83:45334537.

20. Nawroth, P. P., and D. M. Stern. 1986. Modulation of endothelial cell hemostatic properties by tumor necrosis factor. J. Exp. Med. 163:740-745.

21. Scarpati, E. M., and J. E. Sadler. 1989. Regulation of endothelial cell coagulant properties. J. Biol. Chem. 264:20705-20713.

22. Nawroth, P. P., D. A. Handley, C. T. Esmon, and D. M. Stern. 1986. Interleukin 1 induces endothelial cell procoagulant while suppressing cell-surface anticoagulant activity. Proc. Natl. Acad. Sci. USA. 83:3460-3464.

23. Bevilacqua, M. P., J. S. Pober, G. R. Majeau, R. S. Cotran, and M. A. Gimbrone, Jr. 1984. Interleukin 1 (IL-1) induces biosynthesis and cell surface expression of procoagulant activity in human vascular endothelial cells. J. Exp. Med. 160:618-623.

24. Colucci, M., G. Balconi, R. Lorenzet, A. Pietra, D. Locati, M. B. Donati, and $N$. Semeraro. 1983. Cultured human endothelial cells generate tissue factor in response to endotoxin. J. Clin. Invest. 71:1893-1896.

25. Stern, D. M., E. Kaiser, and P. P. Nawroth. 1988. Regulation of the coagulation system by vascular endothelial cells. Haemostasis. 18:202-214.

26. Semeraro, N., R. Triggiani, P. Montemurro, L. G. Cavallo, and M. Colucci. 1993. Enhanced endothelial tissue factor but normal thrombomodulin in endotoxin-treated rabbits. Thromb. Res. 71:479-486.

27. Drake, T. A., J. Cheng, A. Chang, and F. B. Taylor. 1993. Expression of tissue factor, thrombomodulin, and E-selectin in baboons with lethal Escherichia coli sepsis. Am. J. Pathol. 142:1458-1470.

28. Michie, H. R., K. R. Manogue, D. R. Spriggs, A. Revhaug, S. O'Dwyer, C. A. Dinarello, A. Cerami, S. M. Wolff, and D. W. Wilmore. 1988. Detection of circulating tumor necrosis factor after endotoxin administration. $N$. Engl. J. Med. 318:1481-1486.

29. van Deventer, S. J. H., H. R. Büller, J. W. ten Cate, L. A. Aarden, C. E. Hack, and A. Sturk. 1990. Experimental endotoxemia in humans: analysis of cytokine release and coagulation, fibrinolytic, and complement pathways. Blood. 76:2520-2526.

30. Mackay, F., H. Loetscher, D. Stueber, G. Gehr, and W. Lesslauer. 1993. Tumor necrosis factor $\alpha$ (TNF- $\alpha$ )-induced cell adhesion to human endothelial cells is under dominant control of one TNF receptor type, TNF-R55. J. Exp. Med. 177:1277-1286.

31. Thorp, K. M., C. Southern, I. N. Bird, and N. Matthews. 1992. Tumor necrosis factor induction of ELAM-1 and ICAM-1 on human umbilical vein endothelial cells: analysis of tumour necrosis factor-receptor interactions. Cytokine. 4:313-319.

32. Kirchhofer, D., K. S. Sakariassen, M. Clozel, T. B. Tschopp, P. Hadvary, Y. Nemerson, and H. R. Baumgartner. 1993. Relationship between tissue factor expression and deposition of fibrin, platelets, and leukocytes on cultured endothelial cells under venous blood flow conditions. Blood. 81:2050-2058.

33. Clozel, M., H. Kuhn, and H. R. Baumgartner. 1989. Procoagulant activity of endotoxin-treated human endothelial cells exposed to native human flowing blood. Blood. 73:729-733.

34. Markwardt, F. 1992. Hirudin: the promising antithrombotic. Cardiovasc. Drug Rev. 10:211-232.

35. Jaffe, E. A., R. L. Nachman, C. G. Becker, and C. R. Minick. 1973. Culture of human endothelial cells derived from umbilical veins. J. Clin. Invest. 52:2745-2756.

36. Carson, S. D., S. E. Ross, R. Bach, and A. Guha. 1987. An inhibitory monoclonal antibody against human tissue factor. Blood. 70:490-493.

37. Loetscher, H., D. Stueber, D. Banner, F. Mackay, and W. Lesslauer. 1993. Human tumor necrosis factor $\alpha$ (TNF $\alpha$ ) mutants with exclusive specificity for the $55 \mathrm{kDa}$ or $75 \mathrm{kDa}$ TNF receptors. J. Biol. Chem. 268:26350-26357.

38. Sakariassen, K. S., H. Kuhn, R. Muggli, and H. R. Baumgartner. 1988. Growth and stability of thrombi in flowing citrated blood: assessment of plateletsurface interactions with computer-assisted morphometry. Thromb. Haemostasis. 60:392-398.

39. Inauen, W., H. R. Baumgartner, T. Bombeli, A. Haeberli, and P. W. Straub. 1990. Dose- and shear rate-dependent effects of heparin on thrombogenesis induced by rabbit aorta subendothelium exposed to flowing human blood Arteriosclerosis. 10:607-615.

40. Springer, T. A. 1990. Adhesion receptors of the immune system. Science (Wash. DC). 346:425-434.

41. Bevilacqua, M. P., and R. M. Nelson. 1993. Selectins. J. Clin. Invest. 91:379-387.

42. McEver, R. P. 1991. Novel receptors that mediate leukocyte adhesion during inflammation. Thromb. Haemostasis. 65:223-228.

43. Lasky, L. A. 1992. Selectins: interpreters of cell-specific carbohydrate information during inflammation. Science (Wash. DC). 258:964-969.

44. Andoh, K., K. S. Pettersen, C. Filion-Myklebust, and H. Prydz. 1990 Observations on the cell biology of tissue factor in endothelial cells. Thromb. Haemostasis. 63:298-302.

45. Stern, D. M., M. Drillings, H. L. Nossel, A. Hurlet-Jensen, K. S. LaGamma, and J. Owen. 1983. Binding of factors IX and IXa to cultured vascular endothelial cells. Proc. Natl. Acad. Sci. USA. 80:4119-4123.

46. Heimark, R. L., and S. M. Schwartz. 1983. Binding of coagulation factors IX and $\mathrm{X}$ to the endothelial cell surface. Biochem. Biophys. Res. Commun. 111:723-731.

47. Rodgers, G. M., and M. A. Shuman. 1985. Characterization of the interaction between factor $\mathrm{Xa}$ and bovine aortic endothelial cells. Biochim. Biophys. Acta. 844:320-329.

48. Ryan, J., J. Brett, P. Tijburg, R. R. Bach, W. Kisiel, and D. Stern. 1992. Tumor necrosis factor-induced endothelial tissue factor is associated with subendothelial matrix vesicles but is not expressed on the apical surface. Blood. 80:966974. 